Research Article

\title{
A Randomised Open Clinical Study on the Efficacy of 'Sumukti'- an Indigenous Compound on Subjective Symptoms of Madatyaya With Special Reference to Alcohol Dependence
}

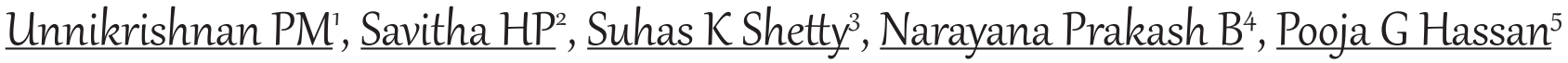 \\ ${ }^{1}$ Clinical Consultant, Department of Manasaroga, Sri Sri College of Ayurvedic Science \& Research Hospital, Bangalore, Karnataka. \\ ${ }^{2}$ Associate Professor, Department of Manasaroga, SDM College of Ayurveda, Hassan, Karnataka. \\ ${ }^{3}$ Professor and Head of Department, Department of Manasaroga, SDM College of Ayurveda, Hassan, Karnataka. \\ ${ }^{4}$ Professor, Department of Kayachikitsa, Dr. Vijay's Ayurvedic Medical College, Varanasi, U.P. \\ ${ }^{5}$ Diet Consultant and Yoga Instructor, Sri Sri College of Ayurvedic Science \& Research Hospital, Bangalore, Karnataka. \\ DOI: https://doi.org/10.24321/2394.6547.201903
}

\section{I $\quad \mathbf{N} \quad \mathbf{F} \quad \mathbf{O}$}

Corresponding Author:

Unnikrishnan PM, Department of Manasaroga, Sri Sri College of Ayurvedic Science \& Research Hospital, Bangalore, Karnataka.

E-mail Id:

drunnikpm@gmail.com

Orcid Id:

https://orcid.org/0000-0002-9034-0871

How to cite this article:

Unnikrishnan PM, Savitha HP, Shetty SK, Narayana PB, Hassan PG. A Randomised Open Clinical Study on the Efficacy of 'Sumukti'- an Indigenous Compound on Subjective Symptoms of Madatyaya With Special Reference to Alcohol Dependence. J Adv Res Ayur Yoga Unani Sidd Homeo 2019; 6(1\&2): 20-25.

Date of Submission: 2019-10-17

Date of Acceptance: 2019-11-27

\section{$\begin{array}{llllllll}\mathbf{A} & \mathbf{B} & \mathbf{S} & \mathbf{T} & \mathbf{R} & \mathbf{A} & \mathbf{C} & \mathbf{T}\end{array}$}

Introduction: With more than half of all alcohol drinkers in India falling into criteria for hazardous drinking, alcohol related disorders are emerging as a major public problem in country. In Ayurveda alcohol related disorders are correlated to Madatyaya. Here we observe the vitiation of Shareerika and Manasika Doshas and the treatment consists of Doshavasechana, Rasayana and Satvavajaya chikitsa. To fulfill all these treatment measures, an indigenous compound named 'Sumukti' which contains 11 drugs with multiple properties of Dosha shamana, Rasayana, Medhya and Yakrit Uttejaka was prepared and administered in the patients of Madatyaya WSR to alcohol dependence.

Aims \& Objectives: To study the efficacy of indigenous compound'Sumukti' on alcohol dependence.

Methodology: 52 patients were screened by using 'Alcohol Dependence Scale'. 30 patients who fulfilled the inclusion criteria of Madatyaya WSR to alcohol dependence from OPD and IPD of SDM College of Ayurveda and Hospital, Hassan were selected and compound 'Sumukti' was given in the dose of $15 \mathrm{ml}$, thrice a day before half an hour of food for 30 days.

Result: There was statistically significant effect seen in subjective parameters with more than $60 \%$ improvement. Moderate improvement (50-74\%) was seen in majority of patients (53.33\%). Marked improvement (75-99\%) also seen in $43.33 \%$ of patients (13).

Conclusion: Compound found effective in subjective symptoms and can be a choice of medicine in alcohol dependence.

Keywords: Madatyaya, Alcohol Dependence, Sumukti 


\section{Introduction and Need for The Study}

Alcohol-related problems occur when a person experiences social, psychological or physical difficulty as a consequence of heavy drinking, or when people close to them are drinking heavily. People of all ages may experience such problems, but older people are more prone to adverse effects because they are more strongly affected by alcohol than younger people. This is because of changes in the way the body processes alcohol as a person age.

Definition of Alcohol Dependence relates to evidence of repeated impairments from alcohol in multiple areas of life functioning, despite which the person returns to drinking. ${ }^{1}$

The National Household Survey of Drug Use in India is the first systematic effort to document the nation-wide prevalence of drug use. Alcohol (21.4\%) was the primary substance used (apart from tobacco) followed by cannabis (3.0\%) and opioids (0.7\%). There was a marked variation in alcohol use prevalence in different states of India (current use ranged from a low of $7 \%$ in the western state of Gujarat (officially under Prohibition) to $75 \%$ in the North-eastern state of Arunachal Pradesh. ${ }^{2}$

According to WHO study Alcohol related problems account for more than $1 / 5$ th of hospital admissions, $18 \%$ of psychiatric emergencies, more than $20 \%$ of all brain injuries, and $60 \%$ of all injuries reporting to India's emergency room. ${ }^{3}$

There is no complete treatment for dependence of Alcohol in allied sciences and even for withdrawal. The drugs used for Alcohol related disorders in allied science have many harmful effects over body. So, there is an immense need to counter the untoward effects of alcohol.

In Ayurveda alcohol related disorders can be correlated to madatyaya. Here we observe the vitiation of shareerika [physical] and manasika [psychological] doshas, which ruins the physical, psychological, social, economic and occupational wellbeing. In Ayurvedic classics treatment of madatyaya consists of doshavasechana [detoxification], Rasayana [rejuvenation] and satvavajaya chikitsa [psychotherapy]. To fulfill all these treatment measures, a compound is prepared and administered in the patients of madatyaya with special reference to Alcohol Dependence.

It is an indigenous compound named sumukti which contains 11 drugs with multiple properties of dosha shamana [passifying vitiated doshas], Rasayana [rejuvenator], Medhya [nootropic] and yakrit uttejaka [hepatoprotective]. There is no direct reference of this compound in any of the classics. Ingredients of compound are Kiratatikta [Swertia Chirata], Guduchi [Tinospora cordifolia], Mandookaparni [Centella asiatica], Haritaki [Terminalia chebula], Vibhitaki [Terminalia bellarika], Amalaki [Emblica officinalis], Bringaraja [Eclipta alba], Ashwagandha [Withania somnifera], Katuki
[Pichrorhiza kurroa], Draksha [Vitis vinifera], Yastimadhu [Glycyrrhiza giabra], Twak [Cinnamomum cassia], Ela [Elettaria cardamomum] and Sarkara [Jaggery]. It was the intention of taking a study on madatyaya with sumukti with objectives; to study the efficacy of indigenous compound - 'sumukti' on alcohol dependence.

\section{Objectives of Study}

To study the efficacy of indigenous compound - 'Sumukti' on alcohol dependence.

\section{Methodology \\ Plan of Study}

- Whole study was carried out in SDM College of Ayurveda and Hospital, Hassan, Karnataka.

- Patients were screened initially by using Alcohol Dependence Scale [ADS]

- $\quad$ Sampling method-simple random sampling

- Study period-1month

- Compound 'Sumukti' was given in the dose of $15 \mathrm{ml}$, thrice a day be forehalfan hour of food for 30 days.

\section{Source of Data}

- 52 patients were screened by using alcohol dependence scale [ADS]

- 32 patients who fulfilled the inclusion criteria of madatyaya WSR to alcohol dependence from OPD and IPD of SDM College of Ayurveda and Hospital, Hassan were selected.

- 30 patients completed the treatment successfully.

\section{Criteria for Diagnosis}

- Diagnosis was made on the basis of general symptoms of madatyaya and ICD-10 diagnostic criteria for alcohol dependence.

\section{Inclusion Criteria}

- Subjects with general symptoms of madatyaya [symptoms of alcohol dependence]

- $\quad$ Age limit- 18- 55

- Subjects of both sexes.

\section{Exclusion Criteria}

- Subjects suffering from other systemic diseases like diabetic mellitus and hypertension.

- Subjects suffering from chronic liver diseases like liver cirrhosis

- Subjects suffering from organic brain diseases.

\section{Plan of Study}

- Patients were screened initially by using alcohol dependence scale [ADS]

- Sampling method - simple random sampling

- Study period - 1 month 
- Compound 'Sumukti' was given in the dose of $15 \mathrm{ml}$, thrice a day before half an hour of food for 30 days.

\section{Assessment Criteria}

A self-prepared scale based on the diagnostic criteria of alcohol dependence according to ICD-10 was prepared and used for assessment on the $1^{\text {st }}$ day and 30th day of treatment.

\section{Statistical Analysis}

- $\quad$ Statistical analysis was done using SPSS VER.16

- 30 completed cases were taken for statistical analysis excluding drop out (2)

- Wilcoxon signed rank test is done to analyze the significance of change in subjective parameters

\section{Result}

In this study all the patients were male (32), more number (7) of patients were belonging to $40-45$ years of age, 26 patients were married, occupation wise maximum (16) patients had physically strained work, socio - economic status wise 23 were belonging to Middle class income group and majority of patients [14] were educated till high school.

All patients had multiple complaints while they came for treatment. Shrama [fatique] was the main complaint which was presented in all patients. 31 patients had sharira kampa [tremors], 30 patients had prajagara [sleeplessness] and alasya [laziness]. Aruchi [tastelessness] was present in 29 patients and 28 patients found to have mandagni [reduced digestive capacity]. Hrillasa [nausea] was seen in 18 patients, mada [acute intoxication] was seen in 17, manda jwara [mild fever] was present in 16 and chardi [vomiting] was seen occasionally in 12 patients. Shoka [sorrow], panduta [paleness], pralapa [irrelevant talking] was present in 9 patients, bhrama [giddiness] in 8 patients and atisara [loose stools], roopanam asatam darshanam [visual hallucinations] was seen in 6 patients each. Apasmara [seizures], bhaya [phobia] were seen in 3 patients each and jrimbha [excessive yawning], pratata trishna [excessive thirst] was seen in 2 patients each.

\section{Discussion}

An effort has been done to assess alcohol dependence in two stages, as physical dependence and psychological dependence. First one is mostly related to body under which tolerance and withdrawal symptoms are categorized. Psychological dependence is mostly related to mind under which craving, salience, loss of control and persistent use is categorized. ${ }^{4}$ In Ayurveda also it is clearly told that Madatyaya is a disease which affect both body and mind simultaneously. There is affliction of Sharirika Dosha [physical ailments], Dushya, Ojas, Buddhi [intelligence], Satva [mind], Indriya [senses] in madatyaya. ${ }^{5}$ So it is clearly known that alcohol dependence is a psychosomatic condition in which both body and mind should be taken care with giving more importance to mind.

Table I.The effect of sumukti on subjective parameter

\begin{tabular}{|c|c|c|c|c|c|c|c|c|c|c|c|c|c|c|}
\hline \multirow{2}{*}{ Parameter } & \multicolumn{2}{|c|}{ Mean } & \multirow{2}{*}{$\begin{array}{l}\% \text { of } \\
\text { red. }\end{array}$} & \multicolumn{3}{|c|}{ Negative ranks } & \multicolumn{3}{|c|}{ Positive ranks } & \multirow{2}{*}{ Ties } & \multirow{2}{*}{ Total } & \multirow{2}{*}{ Z-value } & \multirow{2}{*}{ P-value } & \multirow{2}{*}{ Remarks } \\
\hline & $\mathrm{Bt}$ & At & & $\mathbf{N}$ & $\mathrm{Mr}$ & $\mathrm{Sr}$ & $\mathbf{N}$ & $\mathrm{Mr}$ & $\mathrm{Sr}$ & & & & & \\
\hline Craving & 8.13 & 2.96 & 63.59 & 30 & 15.5 & 465 & 0 & 0 & 0 & 0 & 30 & -4.85 & .000 & $S$ \\
\hline Tolerance & 6.36 & 1.36 & 78.61 & 30 & 15.5 & 465 & 0 & 0 & 0 & 0 & 30 & -4.81 & .000 & $S$ \\
\hline Salience & 6.13 & 2.16 & 64.76 & 30 & 15.5 & 465 & 0 & 0 & 0 & 0 & 30 & -4.81 & .000 & $S$ \\
\hline Loss of control & 6.70 & 1.9 & 71.64 & 29 & 15 & 435 & 0 & 0 & 0 & 1 & 30 & -4.72 & .000 & $\mathrm{~S}$ \\
\hline Persistent use & 7.13 & 1.73 & 75.73 & 30 & 15.5 & 465 & 0 & 0 & 0 & 0 & 30 & -4.81 & .000 & $S$ \\
\hline $\begin{array}{l}\text { Withdrawal } \\
\text { symptoms }\end{array}$ & 5.2 & 1.26 & 75.76 & 30 & 15.5 & 465 & 0 & 0 & 0 & 0 & 30 & -4.80 & .000 & S \\
\hline
\end{tabular}

Table 2.The overall effect of Sumukti on 30 patients of Madatyaya W.S.R. to alcohol dependence

\begin{tabular}{|c|c|c|}
\hline Improvement & Frequency & Percentage \\
\hline No change & 0 & 0 \\
\hline Mild improvement (25-49\%) & 1 & 3.33 \\
\hline Moderate improvement (50-74\%) & 16 & 53.33 \\
\hline Marked improvement (75-99\%) & 13 & 43.33 \\
\hline Complete remission (100\%) & 0 & 0 \\
\hline Total & 30 & 100 \\
\hline
\end{tabular}




\section{Effect of Sumukti in Physiological Dependence}

Madatyaya is a disease with vitiation of all three doshas. ${ }^{6}$ So there will be symptoms of all doshas seen in madatyaya. Considering the withdrawal symptoms, tremors and insomnia may be due to vata dosha, hypertension, increased sweating etc. are due to pitta dosha and nausea, vomiting, weakness etc. seen due to involvement of kapha dosha. In sumukti yastimadhu, draksha mitigate vatapitta dosha, kiratatikta, katuki, vibhitaki mitigate kaphapitta dosha, bringaraja, ashwagandha mitigate vatakapha dosha and guduchi, mandookaparni, haritaki, amalaki mitigate tridosha in their action. That might be the reason compound acted effectively on withdrawal and tolerance symptoms.

Based on properties of Sumukti: Compound has tikta [bitter], kashaya [pungent], madhura [sweet] as predominant rasa [flavor], laghu [light], ruksha [dryness] guna [properties] and madhura [sweet] Vipaka [end digestion]. So due to its rasa [flavor] it might have acted against pitta dosha, by ruksha, laghu properties it acted against kapha dosha and due to its madhura vipaka it acted against vata dosha and there by reduced whole physical symptoms.

Sumukti as Rasayana [rejuvenator]: Madya [alcohol] is having properties which is opposite to ojas. In madatyaya there will be affliction of all dhatus due to vitiation of all three doshas due to which also there will be more withdrawal symptoms and reduced resistant against alcohol. Sumukti is an effective rasayana compound as it contains guduchi ${ }^{7}$, triphala ${ }^{8}$, ashwagandha ${ }^{9}$, draksha ${ }^{10}$ and yastimadh $u^{11}$ which are known rasayana drugs. As per classics rasayana helps a person to attain long life, memory, intelligence, health, good complexion, vitality, clear senses etc. ${ }^{12}$ So it has helped for the improvement of dhatus and mental health hence reduced the physical and psychological symptoms.

Alcohol has major effects on most of the neurochemical systems, depending on the dose, with opposite actions during intoxication and withdrawal. Alcohol acutely increases dopamine and its metabolites, brain imaging reveals enhanced activity in relevant areas of the brain, and chronic drinking changes dopamine receptor numbers and sensitivity. Another key neurochemical is serotonin, with alcohol causing changes in key aspects of this transmitter and associated receptors, and levels of serotonin impact on the amount of alcohol consumed. Additional studies pointed out the indirect actions that alcohol has on the benzodiazepine receptor-sensitive $\gamma$-aminobutyric acid (GABA) complexes in the brain. These effects, especially actions on the GABA type $A$ receptor $\left(G A B A_{A}\right)$, enhance the acute sedating, sleep-inducing, anticonvulsant, and muscle-relaxing effects of alcohol. Finally, alcohol also acutely enhances the functioning of the opioid-related brain systems and impacts on adenosine, neurosteroids, and acetylcholine. ${ }^{13}$
Also, there will be multiple vitamin deficiency mainly thiamine deficiency, can present as any of several neurological syndromes, including a sixth cranial nerve palsy (Wernicke's) and a severe anterograde amnesia (Korsakoff's). So, there is need of antioxidant, immunomodulatory and nutritive drugs for the treatment. ${ }^{14}$

Researches show that many drugs of this compound have immunomodulatory and antioxidant property. Guduchi ${ }^{15}$ and haritaki ${ }^{16}$ has immunomodulatory action and amalaki ${ }^{17}$, draksha $^{18}$, ashwagandha ${ }^{19}$, kiratatikta ${ }^{20}$, yastimadhu ${ }^{21}$ etc. is found very good antioxidant property in various experimental studies. Thus, the compound found effective in physiological dependence.

\section{Effect of Sumukti on Psychological Dependence}

Charaka acharya says that, besides untoward effect of alcohol person continues drinking to get immense pleasure which is attained only through alcohol. ${ }^{22}$ Hence, there is excessive desire towards drinking [craving] which leads to persistent use, loss of control and negligence to alternate pleasure or work [salience]. It is observed in this study that there was vibhrama [distortion] of mana [mind], buddhi [intelligence], bhakti [desires] and Sheela [behavior] which might be due to uncontrolled mano vegas [urges]. Compound Sumukti has Medhya [nootropic] drugs like mandookaparni, yastimadhu, guduchi and ashwagandha. These drugs act at the level of mind and helped the patients to control the vegas (urges) which in turn helped to reduce the vibhramas.

Meaning of medha is to have proper correlation and understanding about the knowledge of the existing objects. Without Medha, knowledge cannot be understood. Dhi, Dhriti and Smriti are the main faculties of medha. Medhya drugs have their action on these 3 faculties. Thus, the compound helped the patients to take a good decision which was beneficial to him which might have the reason there was reduction in the psychological symptoms like craving, loss of control, salience and persistent use.

Body and mind have inseparable relation. So, without vitiation of both manasika [mental ailments] and sharirika Doshas [physical ailments] there will not be complete manifestation of symptoms in madatyaya especially in alcohol dependence. Charaka acharya tried to correlate mano doshas with sharirika dosha by saying desire, sadness, and fear can aggravate vata and anger can aggravate pitta dosha. ${ }^{23}$ That may be the reason most of time patients will be anxious to avoid withdrawal symptoms due to which they will go for persistent use of alcohol and get loss of control over it. So, by reducing the sharirika [physical] symptoms it will help the patients to control his alcohol intake behavior i.e. Manovega and vice versa. Compound sumukti has drugs which reduce both sharirika and manasika dosha which we 
already discussed in physical dependence. Hence, it acted on both body, mind and reduced the symptoms effectively.

Up to 80 percent of alcoholic people report symptoms of sadness or anxiety during the course of their disorder. Experimental studies show that Withania somnifera and centella asiatica are very much effective in oxidative stress and these both are good anxiolytic drugs. ${ }^{24}$ centella asiatica [mandookaprni], withania somnifera [ashwagandha], Tinospora cordifolia [Guduchi] and Glycirrhiza glabra [yastmadhu] has potential nootropic effect. ${ }^{25}$ In another studies, it found that Centella asiatica has neuroprotective action. $^{26}$

\section{Conclusion}

There was statistically significant effect seen in subjective parameters with more than $60 \%$ improvement. Compound found effective in all symptoms hence can be a choice of medicine in alcohol dependence especially in withdrawal stage.

\section{Conflict of Interest: None}

\section{References}

1. Kaplan and Sadock. Comprehensive text book of psychiatry. Sadock BJ, Sadock VA, ed., $8^{\text {th }}$ edition. Lippincott Williams and Wilkins, USA. 2005. Vol I. 1169.

2. Murthy P, Manjunatha N, Subodh BN, Chand PK, Benegal $V$ et al. Substance use and addiction research in India. IJPsy 2010; 52(7): 189-199. Available from: http://www. indianjpsychiatry.org/article.asp?issn=0019-5545; yea r=2010; volume=52;issue=7; spage=189; epage=199; au last=Murthy [PubMed/ Google Scholar].

3. Prasad R. Alcohol use on the rise in India. 2009. pp.17-18. Available from: http://www.thelancet.com/ journals/lancet/article/PIIS0140-6736(08)61939-X/ fulltext.

4. Kaplan and Sadock. Comprehensive text book of psychiatry. Sadock BJ, Sadock VA, ed., $8^{\text {th }}$ edition. Lippincott Williams and Wilkins, USA. 2005. Vol I. 1139.

5. Charaka A, Chakrapanidatta D. In: Acharya JT (eds.) Charaka Samhita with Ayurveda Deepika commentary. Reprint 2009 ed. Chaukhamba Prakashan, Varanasi. 2009, 584.

6. Charaka A, Chakrapanidatta D. In: Acharya JT (eds.) Charaka Samhita with Ayurveda Deepika commentary. Reprint 2009 ed. Chaukhamba Prakashan, Varanasi. 2009, 587.

7. The Ayurvedic Pharmacopoeia of India. National institute of Science Communication and Information Resources [NISCAIR], CSIR, New Delhi. 2006. Part I; Vol I. 41-42. Available from: ayurveda.hu/api/API-Vol-1.pdf

8. The Ayurvedic Pharmacopoeia of India. National institute of Science Communication and Information Resources [NISCAIR], CSIR, New Delhi. 2006. Part I;
Vol I. 47-48. Available from: http://www.ayurveda. hu/api/API-Vol-1.pdf.

9. The Ayurvedic Pharmacopoeia of India. National institute of Science Communication and Information Resources [NISCAIR], CSIR, New Delhi. 2006. Part I; Vol I. 15-16. Available from: http://www.ayurveda. hu/api/API-Vol-1.pdf.

10. The Ayurvedic Pharmacopoeia of India. National institute of Science Communication and Information Resources [NISCAIR], CSIR, New Delhi. 2006. Part I; Vol III. 45-46. Available from: http://www.ayurveda. hu/api/API-Vol-1.pdf.

11. The Ayurvedic Pharmacopoeia of India. National institute of Science Communication and Information Resources [NISCAIR], CSIR, New Delhi. 2006. Part I; Vol I. 127-128. Available from: http://www.ayurveda.hu/ api/API-Vol-1.pdf.

12. Charaka A, Chakrapanidatta D. In: Acharya JT (eds.) Charaka Samhita with Ayurveda Deepika commentary. Reprint 2009 ed. Chaukhamba Prakashan, Varanasi. 2009, 491.

13. Kaplan and Sadock. Comprehensive text book of psychiatry. Sadock BJ, Sadock VA, ed., $8^{\text {th }}$ edition. Lippincott Williams and Wilkins, USA. 2005. Vol I. 1172.

14. Kaplan and Sadock. Comprehensive text book of psychiatry. Sadock BJ, Sadock VA, ed., $8^{\text {th }}$ edition. Lippincott Williams and Wilkins, USA. 2005. Vol I. 1173.

15. Bishayi B, Roychowdhury S, Ghosh S, Sengupta M. Hepatoprotective and immunomodulatory properties of Tinospora cordifolia in $\mathrm{CCl} 4$ intoxicated mature albino rats. The Journal of Toxicological Sciences 2002; 27(3): 139-146. [PubMed/ Google Scholar/ ResearchGate].

16. Aher V, Wahi A. Immunomodulatory Activity of Alcohol Extract of Terminalia chebula Retz Combretaceae. Tropical Journal of Pharmaceutical Research 2011; 10(5): 15670. Available from: https://www.ajol.info/ index.php/tjpr/article/view/71665 [Google Scholar].

17. Reddy VD, Padmavathi P, Paramahamsa $M$, Varadacharyulu NC. Amelioration of alcohol-induced oxidative stress by Emblica officinalis (amla) in rats. Indian J Biochem Biophys 2010; 47(1): 20-25. [PubMed/ Google Scholar].

18. Pari L, Suresh A. Effect of grape (Vitis vinifera L.) leaf extract on alcohol induced oxidative stress in rats. Food and Chemical Toxicology 2008; 46(5): 1627-1634. [PubMed/ Google Scholar/ ResearchGate].

19. The Ayurvedic Pharmacopoeia of India. National institute of Science Communication and Information Resources [NISCAIR], CSIR, New Delhi. 2006. Part I; Vol II. 21-24. Available from: http://www.ayurveda. hu/api/API-Vol-1.pdf.

20. Balasundari $P$, Singh SK, Kavimani S. Free radical scavenging of xanthones from Swertiachirata 
Buchham and tumor cell growth inhibition. Main Group Chemistry 2005; 4(3): 177-185. Available from: https://www.tandfonline.com/doi/ abs/10.1080/10241220500324209 [Google Scholar].

21. Young-Won C, Hyun-Ah J, Yue L, et al. Anti-oxidant constituents of the roots and stolons of Licorice (Glycyrrhiza glabra). Journal of Agric Food Chem 2007; 55(12): 4691-4697. Available from: https://pubs.acs. org/doi/abs/10.1021/jf0703553 [PubMed/ Google Scholar/ ResearchGate].

22. Charaka A, Chakrapanidatta D. In: Acharya JT (eds.) Charaka Samhita with Ayurveda Deepika commentary. Reprint 2009 ed., Chaukhamba Prakashan, Varanasi. 2009, 585.

23. Charaka A, Chakrapanidatta D. In: Acharya JT (eds.) Charaka Samhita with Ayurveda Deepika commentary. Reprint 2009 ed., Chaukhamba Prakashan, Varanasi. 2009, 586.

24. Mathew M, Sarada S. Evaluation of the antiamyloidogenic potential of nootropic herbal extracts in vitro. International Journal of Pharmaceutical Sciences \& Research 2012; 3(11): 4276-4280. Available from: http://ijpsr.com/bft-article/evaluation-of-the-antiamyloidogenic-potential-of-nootropic-herbal-extractsin-vitro/?view=fulltext [Google Scholar].

25. Reena K, Girish KJ, Abhimanyu K. Nootropic herbs (Medhya Rasayana) in Ayurveda: An update. Pharmacogn Rev. 2012; 6(12): 147-153. [PubMed/ Google Scholar/ ResearchGate].

26. Krishnamurthy RG, Marie-Claude S, Daniel Z, Jiangyong M, Mark BF, Eric JG et al. Asiatic acid, a pentacyclic triterpene from Centella asiatica, is neuroprotective in a mouse model of focal cerebral ischemia. Journal of Neuroscience Research 2009; 87(11): 2541-2550. [PubMed/ Google Scholar]. 